\begin{tabular}{|l|l|l||}
\hline \multicolumn{2}{|c|}{ PublisherInfo } \\
\hline \hline PublisherName & $:$ & BioMed Central \\
\hline \hline PublisherLocation & $:$ & London \\
\hline \hline PublisherImprintName & $:$ & BioMed Central \\
\hline \hline
\end{tabular}

\title{
Many ways to make a breast tumor
}

\begin{tabular}{|l|l|l||}
\hline \multicolumn{2}{|c|}{ ArticleInfo } \\
\hline \hline ArticleID & $:$ & 3748 \\
\hline \hline ArticleDOI & $:$ & $10.1186 /$ gb-spotlight-20000821-01 \\
\hline \hline ArticleCitationID & $:$ & spotlight-20000821-01 \\
\hline \hline ArticleSequenceNumber & $:$ & 185 \\
\hline \hline ArticleCategory & $:$ & Research news \\
\hline \hline ArticleFirstPage & $:$ & 1 \\
\hline \hline ArticleLastPage & $:$ & 2 \\
\hline \hline & & RegistrationDate : 2000-08-21 \\
ArticleHistory & $:$ & OnlineDate $\quad: \quad 2000-08-21$ \\
\hline \hline ArticleCopyright & $:$ & BioMed Central Ltd2000 \\
\hline \hline ArticleGrants & $:$ & \\
\hline \hline ArticleContext & $:$ & 130591111 \\
\hline \hline
\end{tabular}




\section{William Wells}

Email: wells@biotext.com

In the 17 August Nature Perou et al. present a DNA microarray analysis of 65 human breast tumor specimens from 42 different individuals (Nature 2000, 406:747-752). Of the 8,102 genes analyzed, 1,753 varied in abundance at least fourfold in at least three samples. These genes could be clustered into groups that correlated with mitotic index, regulation of the interferon pathway, and the relative abundance of endothelial cells, stromal cells, adipose cells, B or T cells and macrophages. Expression patterns derived from a single patient at different times were usually very similar, but analysis of all the samples emphasized the number of different ways that a breast tumor can develop. Nevertheless, the samples could be subdivided into certain groups; a report correlating these groupings with clinical data will appear elsewhere.

\section{References}

1. Nature magazine, [http://www.nature.com/nature/]

2. Cluster analysis and display of genome-wide expression patterns. 